\title{
Go-Business Application: Optimization of Young Entrepreneurs as A Mobilizer of Economy
}

\author{
Atika Dinna Hastanti, Febriana Aminatul Khusna \\ English Education Department, Faculty of Education and Teacher Training, Universitas Tidar \\ Jalan Kapten Suparman Nomor 39, Kecamatan Magelang Utara, Kota Magelang, 56116, Jawa Tengah, Telp. (0293) 364113 Fax. (0293) 362438 \\ Email: admin@untidar.ac.id
}

\begin{abstract}
This research discusses about the prototype of the Go-Business Application design for optimizing young entrepreneurs as a economic movement. In modern era, the technology have developed rapidly into various fields for instance, education, social, political, cultural, and even economic. This is a great opportunity for entrepreneurs to get their market through technological advancements. Based on data from the Central Statistics Agency (BPS), the percentage of the population using the telephone continues to increase, until 2017 reaching 59.59\%. The internet usage also increased during the 2013-2017, which was agreed from a comparison with the population accessing the internet in 2013 around $14.90 \%$ to $32.34 \%$ in 2017 . This is consistent with the topic that we developed by science, computer and technology Information. This research use descriptive method and questionnaire. Descriptive method is used to describe the phenomena that are taking place now or in the past, and collect data from journals and other sources. Then the questionnaire method, the implementation of this method is by asking questions to respondents about the research variables to obtain information. This was to obtain valid and targeted data, also to find out the effectiveness of the Go-Business Application for optimizing young entrepreneurs as a mobilizer of economy.
\end{abstract}

Keywords: Application, Questionnaire, Entrepreneur, Economy, Technology.

\section{INTRODUCTION}

Economics is a branch of social science that cannot be separated in everyday life, because through economics, every human being can fulfill his life needs both as individuals and as a unit or known as an organization. In this case, the organization which is a unit of each individual is called the state. In this era business has always been the active agent of progress, through innovation and new products, by encouraging the spread of technology, or lowering costs through productivity, by improving services and enhancing quality, and thereby making the good things of life available and affordable. Industry is the part of an economy that produces material which are highly technology. Ever since the beginning of industrialization, technological leaps have led to paradigm shifts which ex-post named "industrial revolutions or industry 4.0". Industry 4.0 represents a special challenge for businesses or entrepreneur, they must work hard to marketing their product. This era refers to a new phase in the Industrial Revolution that focuses heavily on interconnectivity, automation, machine learning, and real-time data. In business world every competition have another effect and can change anything, that's the possible things of business the entrepreneur have to create the new innovation of business.

Based on data from the Central Statistics Agency (BPS), the percentage of the population using the telephone continues to increase, until 2017 reaching $59.59 \%$. The internet usage also increased during the
2013-2017, which was agreed from a comparison with the population accessing the internet in 2013 around $14.90 \%$ to $32.34 \%$ in 2017. The Ministry of Cooperatives and SMEs releases BPS-processed data and concludes that there is an increase in the number of entrepreneurs. From the previous $1.6 \%$ to $3.1 \%$ of the population. That figure is encouraging because it has broken the psychological limit of $2 \%$. The number of entrepreneurs in a country is often considered an indicator of progress. The benchmark is at least $2 \%$ of the total population must work as entrepreneurs. With a population of 250 million, this country must have at least 5 million entrepreneurs. Compared to neighboring countries, it must be admitted, we are outnumbered. Singapore is at $7 \%$, Malaysia is $5 \%$, Thailand is $4.5 \%$, and Vietnam is $3.3 \%$. America and Japan have soared far. Ten percent of its citizens are in the business world. The one of the big problem or challenge of entrepreneur is the strategy of marketing the product. Sometimes they don't know the best way to market the products and services: print, online, mobile, advertising, etc.

In modern era, many programmers create the application for helping many people in their activity. They also multiply specially application for business people or entrepreneur. Many people choose application for shopping, because it is very convenient for used. This research discusses about the prototype of the GoBusiness Application design for optimizing young entrepreneurs as a economic movement. In modern era, the technology have developed rapidly into various fields for instance, education, social, political, cultural, 
and even economic. This research use descriptive method and questionnaire. Descriptive method is used to describe the phenomena that are taking place now or in the past, and collect data from journals and other sources. Then the questionnaire method, the implementation of this method is by asking questions to respondents about the research variables to obtain information. This was to obtain valid and targeted data, also to find out the effectiveness of the Go-Business Application for optimizing young entrepreneurs as a mobilizer of economy.

\section{MATERIAL AND METHOD}

\section{Study Area}

Moreover, Endraswara (2011) gives the important features of qualitative research in investigating the literature, such as the researcher is the key of instrument that readsthe literature thrifty, the research is done descriptively which elaborated in the form of words or pictures, and the process is more priority than result, because literature establishes interpretations. Rather, questionnaire is defined as a document containing questions and other types of items designed to solicit information appropriate for analysis (Babbie, 1990:377). Questionnaire is equally used in survey research, experiments and other for observation. In edition, people ask with the different questions for analysis the research. In other hand, questionnaire contains a series of questions designed to gather particular information. It is used in different fields like business, sciences, and social sciences. It is a research instrument having sequence of questions with a specific purpose to get information from respondents and extract desired statistical data.

Understanding Entrepreneurship, which means people who buy goods at a fixed price even though that person does not yet know how much the price of goods to be sold. Entrepreneurship is often also called entrepreneur, which means the characteristics of courage, virtue, exemplary in taking risks originating from one's own abilities. However entrepreneur and entrepreneur actually have different meanings. Entrepreneurs do not have a vision of business development while entrepreneurs are able to continue to develop and try other businesses. Youth Business International (YBI) has helped a significant number of young entrepreneurs through its network of business programmes worldwide. It provides young people, who have little more than a bright idea and the determination to succeed, with a start-up loan and the services of a volunteer mentor.

The fluctuating Indonesian economy affects the conditions and progress of people's lives, so the government tries to increase its economic growth, which is pursued by the government through various policies to promote balanced economic growth. Some efforts to achieve it, such as: offering various facilities to foreign investors so that they are interested in investing their business capital, promoting quality labor with affordable wages. Economic policy of a country also cannot be separated from the understanding or economic system held by a country's government, such as the economic system of Capitalism, Socialism, Mixed, and the Islamic economic system. Of course the government, as controlling the economy of a country, adheres to one of the economic systems as a basis for making economic policy. Whatever the economic system that is held by a government, the economic system is believed to be the best economic system for the country's economy led by a government even though later in the economic system that is held has various weaknesses.

Besides that the most common problem for entrepreneurs, especially young entrepreneurs is a forum. They don't have a promising place for product marketing. They tend to market their products only through social media. It's the best way they have, rather than not marketing their products. It is unfortunate if their ideas are abandoned. In case we recall that, young entrepreneurs are one of the drivers of the country's economy if properly developed. One that can be given to help them is, by giving them facilities for where they work through the business world. Giving them facilities is the task of the government and all of us. Base of the case, we can conclude that the new or the young entrepreneur need a places to marketing their product. Base on go-business application, the young entrepreneur have a places to marketing their product. This application was setting for those marketing, but with the small context or small area. Meaning the small area such as, just in the university area.

\section{Procedures}

In this research has some steps that included on method and materials. That steps are geting information from respondents by using google form and then the prototype design Go-Business application. The steps are as follows:

\section{Geting Information From Respondents By Using Google Form}

The questionnaire of Google form is used, because it is convenient to accesses. This is a tool that allows collecting information from users via a personalized survey or quiz.

This steps we find the respondent to get information about effectiveness survey of Go-Business application design. The respondents are from students who have a business or are running a business. The link of Google Form is shared through social media such as WhatsApp application. It is shared for two days or a long time until get the many respondents. The questions in the from are about the effectiveness survey of Go-Business application design economic problems, the developments of technological, obstacles in running a business, the role 
of Go-Business application design, and the effectiveness of this application design. The answers of some that questions, which are about agreement or not and responses and suggestions regarding this research.

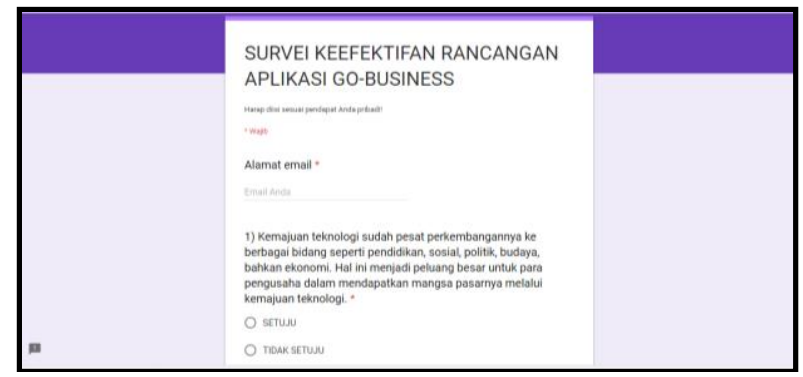

Figure 1. Effectiveness survey of Go-Business application design.

\section{How the application design works and application} features

In this steps are consists, what the application design works and application features look like. In this procedures are consists from some part of features in the prototype design, there are:

a. The Logo of Go-Business application;

b. The initial display of the application;

c. The seller's menu display in the application;

d. The seller account registration display;

e. Initial display of the seller's account;

f. Display to upload sales;

g. The customer's menu display in the application;

h. The customer account registration display.

3. The combination of respondent responses and application prototype exposure

In this step the results of respondents who already filled the Google Form question thath can get the point of problem solving. It is about the hopes of respondents about the application prototype, the problem about their business and another problems about economics. this can be obtained the relationship between the effectiveness of the prototype with economic problems, especially product marketing.

\section{Data Analysis}

In this section of the date analysis, the researcher use questionnaire to looking for the real information. In this analysis the questionnaire is not far with the literature study, questionnaire is equally used in survey research, experiments and other for observation. In edition, people ask with the different questions for analysis the research. In other hand, questionnaire contains a series of questions designed to gather particular information. Literature study of collecting data by reading reference books or documentation relating to research on geographic information systems and mapping of student potential at universities. Google Forms is a survey administration that is included in the Google Drive office suite along with Google Docs, Google Sheets, and Google Slides. Forms features all of the collaboration and sharing features found in docs, sheets, also slides. The questionnaire of Google Form is used, because it is convenient to accesses. This is a tool that allows collecting information from users via a personalized survey or quiz. Then, information is then collected and automatically connected to a spreadsheet. The spreadsheet is populated with the survey and quiz responses. This the question that the researcher used:

1. The development of technology has been rapid development in various fields such as education, social, political, cultural, even economic. This is a great opportunity for entrepreneurs to get their market prey through technological advancements.

2. Do you often find it difficult to market a product and get a lot of customers, especially for you young entrepreneurs?

3. What hinders your product marketing?

4. E-commerce is a business process using technology that connects companies, consumers and the public in the form of electronic transactions and the exchange or sale of electronic goods, services and information. Do you agree that e-commerce can simplify and improve transaction effectiveness?

5. Do you know the Go-Business Application? GoBusiness application is one prototype of an ecommerce application design that has several advantages, including?

1) The design of an e-commerce application prototype that can make it easier between sellers and buyers.

2) You can market the product in the application.

3) Can make it easier for students especially those who are starting new businesses in product marketing because the design of this application is made for young entrepreneurs.

4) The selling price, unit price, location of receipt of goods, location of cod, endurance of goods can also be openly listed in this application.

5) Become a place for students to develop their new business.

6) There are many application features for sellers and buyers. Do you agree that the design of this application is effective for marketing products especially for young / new entrepreneurs?

6. What do you think about the effectiveness of the design of Go-Business applications for entrepreneurship?

The target in this study was the students. Some reasons why the researchers only take the scope of students that reasons are as follows:

1. Accommodating student creativity in entrepreneurship.

2. Help marketing the student's own product.

3. Distribute sales products from entrepreneurship courses.

4. Empowering students to become young entrepreneurs. 
5. One of the university's vision is that it is entrepreneurial.

When we look at the reason, we can conclude that we need a forum to marketing the product of students in Universitas Tidar Magelang. Via Go-Business application we can make a forum for students that can to be a marketing their product. Rather, when there is no forum, their product can't develop especially to marketing the product.

\section{RESULTS AND DISCUSSION}

Result-1 (Application Design Works and Application Features)

In this steps are consists, what the application design works and application features look like. In this procedures are consists from some part of features in the prototype design, there are:

\section{Information from Respondents by Using Google Form}

The result of this research is comparison between the researcher argument and the responses. Almost all the argument of the researcher corresponding with the responses. Following the questions from the point $\mathrm{C}$ in date analysis, the researches answer with the several arguments. The questions from date analysis about the socioeconomic problem, the experience difficulties in product marketing, agreement if there is a place like application for product marketing, there is an application that helps product sales can help overcome sales or marketing problems and give us advice or feedback if there is an application that can help product marketing.

2. How The Application Design Works and Application Features.

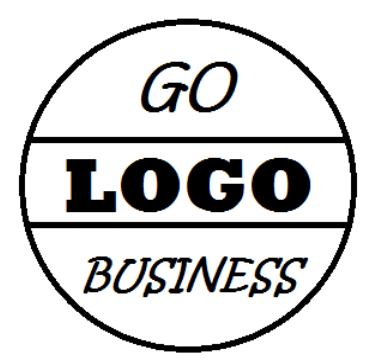

Figure 2. The Logo of GoBusiness application

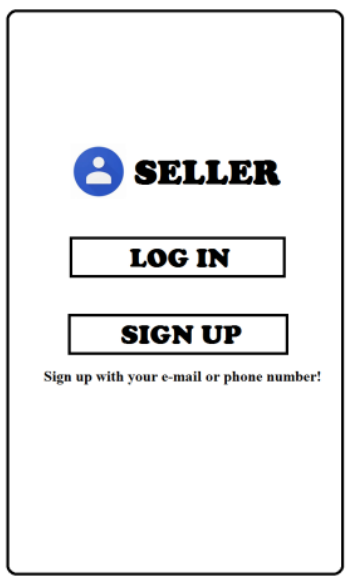

Figure 4. The seller's menu display in the application

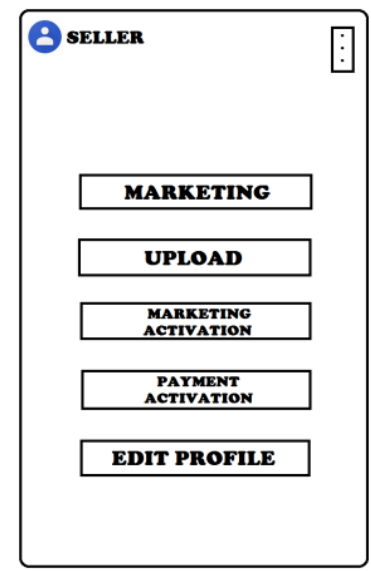

Figure 6. Initial view of the seller's account

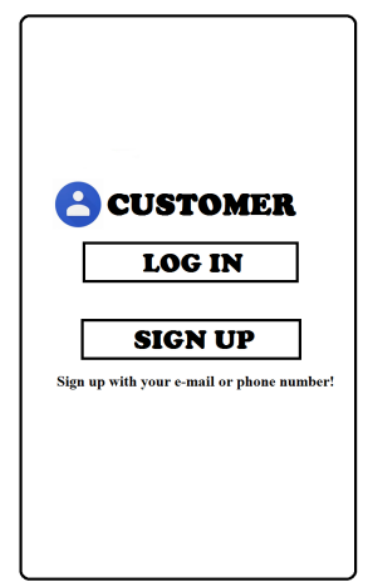

Figure 8. The customer's menu display in the application

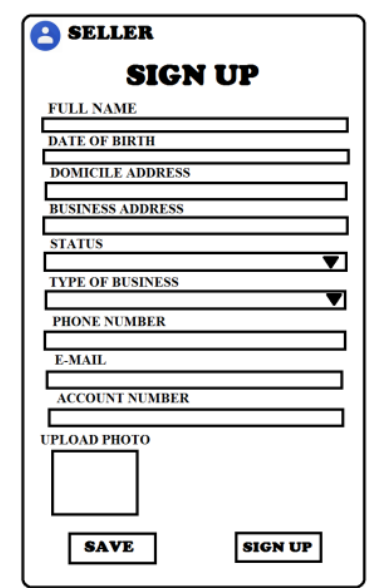

Figure 5. The seller account registration display

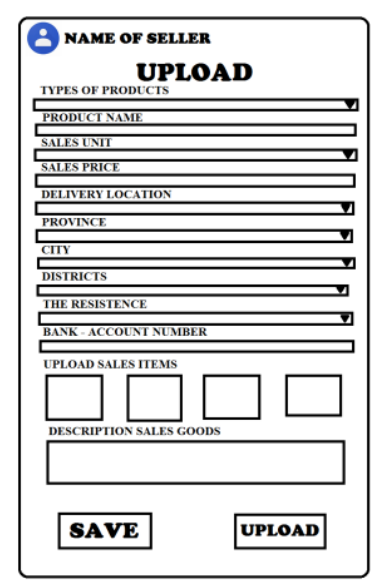

Figure 7. Display to upload sales

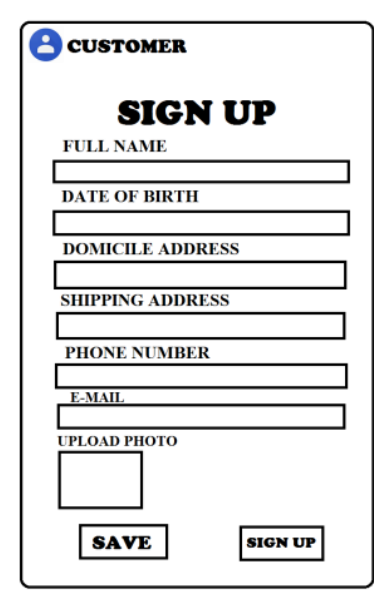

Figure 9. The customer account registration display

1) The Logo of Go-Business Application

Based on figure 2. The Logo of Go-Business application. That is rough overview of the application, in the real logo on application are included the left half is the golden brown gear wheel, the right half is the internet network image and technological advancements, for the circle logo with the go-business letters on the top and bottom with golden red, in the middle the logo contains the hand 
being a handshake that shows the agreement of the buyer and seller, and the basic color of the logo is blue.

2) The Initial Display of The Application

Based on figure 3. The initial display of the application. In this view consists of two features, that are "seller" and "customer". it means that feature about the all menu to use for the seller and customer.

3) The Seller's Menu Display in The Application

Based on figure 4. The seller's menu display in the application. In this menu consists of some features, that are "log in, sign up and how you can sign up by using email or phone number". Log in button are used to the seller if already have the account. The sign up button ones are use to registrating the seller if don't have the account before.

4) The Seller Account Registration Display

Based on figure 5. The seller account registration display. In this menu consists of some feature to registration by seller. That features are full name filled in with the seller's name, date of birth filled in with seller's date of birth. Then, the others features is like domicile address, business addres, status, type of business, phone number, email and accound number filled in according to the seller's personal data. The next is upload photo to account, and than you can save the information in this menu or directly sign up your information to get your new account.

5) Initial Display of The Seller's Account

Based on figure 6. Initial view of the seller's account. This menu consists of some fetures, that are marketing, upload, marketing activation, payment activation, and edit profile. Marketing feature are used to look our the sales already uploaded. Upload feature are used to upload our sales, marketing activation feature are used to look our activation marketing by the customer who order our sales. The, payment activation feature are used to look the customers' payment who already ordered our sales. The last is edit profile feature are used to edit our profile.

\section{6) Display to Upload Sales}

Based on figure 7. Display to upload sales. This menu consists of some fetures, that are type of products, product name, sales unit, delivery location, province, city, districts, the resistence, bank account number, upload sales items, description sales goods. That are filled according to the product being sold. If there will be COD systems to transaction, there must input the spesificly addres to COD.

7) The Customer's Menu Display in The Application

Based on figure 8 . The customer's menu display in the application. In this menu consists of some features, that are "log in, sign up and how you can sign up by using email or phone number". Log in button are used to the customer if already have the account. The sign up button ones are use to registrating the customer if don't have the account before.

8) The Customer Account Registration Display

Based on figure 9. The customer account registration display. In this menu consists of some feature to registration by customer. That features are full name filled in with the customer's name, date of birth filled in with customer's date of birth. Then, the others features is like domicile address, shipping addres, phone number, and email filled in according to the customer's personal data. The next is upload photo to account, and than you can save the information in this menu or directly sign up your information to get your new account.

\section{Result-2 (The Results by Geting Information to The Respondents)}

This is the data which from geting information to the respondents that are many respondents agree with this Go-Business application prototype design. The results by that research to the respondents $100 \%$ agreed with this research. However, they hope that this application will be realized soon so that the benefits can be felt together. Based on this research we can conclude many of the agreed with this Go-Business application prototype design.

Tabel 1. The Results by Geting Information to The Respondents

\begin{tabular}{|c|c|c|c|}
\hline No. & Question & Scale \% & Responses \\
\hline 1. & $\begin{array}{l}\text { The development of technology has been rapid development in } \\
\text { various fields such as education, social, political, cultural, even } \\
\text { economic. This is a great opportunity for entrepreneurs to get } \\
\text { their market prey through technological advancements. }\end{array}$ & $\begin{array}{l}100 \% \\
\text { Agree }\end{array}$ & - \\
\hline 2. & $\begin{array}{l}\text { Do you often find it difficult to market a product and get a lot } \\
\text { of customers, especially for you young entrepreneurs? }\end{array}$ & $\begin{array}{l}100 \% \\
\text { Agree }\end{array}$ & - \\
\hline 3. & What hinders your product marketing? & - & $\begin{array}{l}\text { 1) I am a psychic. } \\
\text { 2) Same product rivals. } \\
\text { 3) Network. } \\
\text { 4) Advertise products and get consumers. } \\
\text { 5) Time. } \\
\text { 6) Lack of public knowledge/prospective buyers, especially in the } \\
\text { area of Magelang about the products I sell, which are products }\end{array}$ \\
\hline
\end{tabular}


that support a minimal lifestyle garbage.

7) Time, vehicle.

8) Ignorance about products, lack of channels

9) Bad intentions.

10) Relation

11) Lack of ability in marketing products, do not yet understand the best marketing strategies for the current era.

12) Not interested in the market and many people who sometimes do not know but are already soupy.

4. E-commerce is a business process using technology that
connects companies, consumers and the public in the form of
electronic transactions and the exchange or sale of electronic
goods, services and information. Do you agree that e-
commerce can simplify and improve transaction effectiveness?
Do you know the Go-Business Application? Go-Business
application is one prototype of an e-commerce application
design that has several advantages, including:
1) The design of an e-commerce application prototype that can
make it easier between sellers and buyers.
2) You can market the product in the application.
3) Can make it easier for students especially those who are
starting new businesses in product marketing because the
design of this application is made for young entrepreneurs.
4) The selling price, unit price, location of receipt of goods,
location of cod, endurance of goods can also be openly
listed in this application.
5) Become a place for students to develop their new business.
6) There are many application features for sellers and buyers.
Do you agree that the design of this application is effective
for marketing products especially for young / new
entrepreneurs?

6. What do you think about the effectiveness of the design of GoBusiness applications for entrepreneurship?

\section{$100 \%$}

Agree

$100 \%$

Agree

-


through productivity, by improving services and enhancing quality, and thereby making the good things of life available and affordable. Industry 4.0 represents a special challenge for businesses or entrepreneur, they must work hard to marketing their product. The one of the big problem or challenge of entrepreneur is the strategy of marketing the product. Sometimes they don't know the best way to market the products and services: print, online, mobile, advertising, etc.

Based on that case its research give the a sollution about the strategy of marketing the product. In this era many competitors in the business world. Go-Business application prototype design can be one of the solutions in terms of product marketing and as a container for production sales. The data which from geting information to the respondents that are many respondents agree with this Go-Business application prototype design. The results by that research to the respondents $100 \%$ agreed with this research. However, they hope that this application will be realized soon so that the benefits can be felt together. Their opinion on this application because it can help marketing and sales of production and can facilitate the transaction process.

The Go-Business application prototype design are consists from some part of features in the prototype design, there are:

1) The Logo of Go-Business application;

2) The initial display of the application;

3) The seller's menu display in the application;

4) The seller account registration display;

5) Initial display of the seller's account;

6) Display to upload sales;

7) The customer's menu display in the application;

8) The customer account registration display;

The feature is detailed to separate seller and buyer accounts. the feature will also be developed according to market and business world needs. Based on that prototype fatures it will help many young entrepreneur. However, we realize to realize this application not only need from us researchers but we also want to collaborate with people who are experts in the field of technology. This research will not succeed without the contribution of people who are experts in their fields. In this research we hope this application can be implemented.

\section{CONCLUSIONS}

In this era business has always been the active agent of progress, through innovation and new products, by encouraging the spread of technology, or lowering costs through productivity, by improving services and enhancing quality, and thereby making the good things of life available and affordable. The one of the big problem or challenge of entrepreneur is the strategy of marketing the product. In modern era, many programmer create the application for helping many people in their activity. In business world every competition have another effect and can change anything, that's the possible things of business the entrepreneur have to create the new innovation of business. Based on that case its research give the a sollution about the strategy of marketing the product. The Go-Business application prototype design can be one of the solutions in terms of product marketing and as a container for production sales. However, we realize to realize this application not only need from us researchers but we also want to collaborate with people who are experts in the field of technology.

\section{ACKNOWLEDGEMENTS}

Praise God Almighty, for the presence of plenty of mercy and his grace, so that the writer can complete the thesis with the title "Go-Business Application: Optimization of Young Entrepreneurs as A Mobilizer Of Economy". This is to meet one of the research studies in order to obtained in Faculty of Science and Technology, Islamic State University of Sunan Kalijaga Yogyakarta. May Allah SWT always bestow grace, health, gifts and blessings in the world and in the hereafter over budi good that has been given to the author and the many people who have contributed to this research. The final word the author realized that in the writing of this writingis still far from perfection. Therefore, the authors invoke suggestions and criticisms which is build for the sake of perfection and may be useful for all of us.

\section{REFERENCES}

Cull, J, (2006). Mentoring young entrepreneurs: what leads to success?. International Journal of Evidence Based Coaching and Mentoring, 4(2). Accessed from http://ijebcm.brookes.ac.uk/documents/vol04issue2-paper01.pdf [November 24, 2019].

Elizabeth, R. (2017). Akselerasi pemberdayaan dan peningkatan kompetensi dalam sistem produksi untuk mengatasi permasalahan ekonomi di Indonesia. Journal of Scientch Research, 2(1). Accessed from http://ojs.ekasakti.org/index.php/UJSR/article/view/175 [November 24, 2019].

Kharistiani, E. \& Aribowo, E. (2013). Sistem informasi geografis pemetaan potensi SMA/SMK berbasis web (studi kasus: Kabupaten Kebumen. Journal of Informatics Engineering, 1(1). Accessed from https://media.neliti.com/media/publications/211222-sisteminfotmasi-geografis-pemetaan-pote.pdf e-ISSN: 2338-5197 [November 24, 2019].

Lasi, H. \& Fettke, P. (2014). Application-pull and technologypush as driving forces for the fourth industrial revolution. Business \& Information Systems Engineering, 6. Accessed from https://link.springer.com/article/10.1007/s12599-0140334-4 [November 24, 2019]. 
THIS PAGE INTENTIONALLY LEFT BLANK 